\title{
CONTINUITY AND CHANGE
}

\section{A JOURNAL OF SOCIAL STRUCTURE, LAW AND DEMOGRAPHY IN PAST SOCIETIES}

\author{
VOLUME 11 PART 1 \\ MAY 1996
}

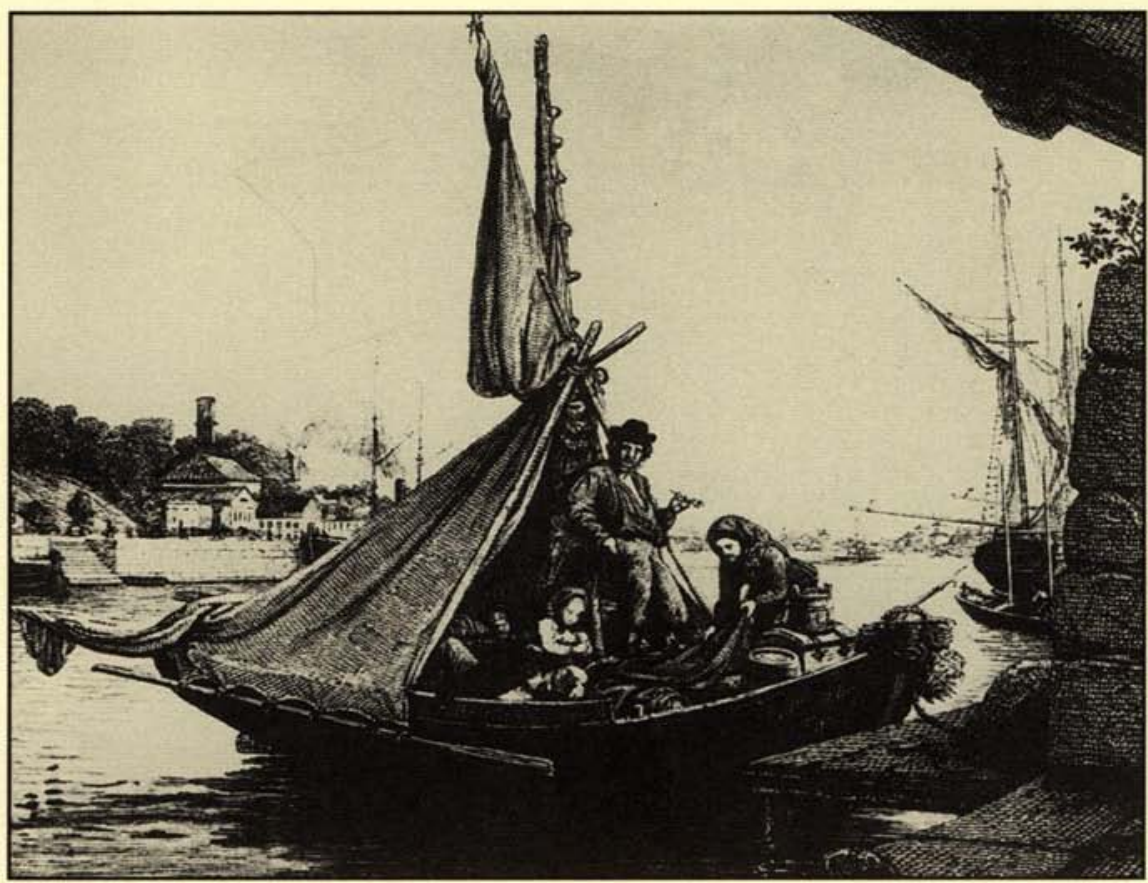


A journal of social structure, law and demography in past societies.

\section{Tulane University Law School}

\section{Cambridge Group for the History of Population and Social Structure}

\section{EDITORS}

LLOYD BONFIELD, Tulane University Law School, Joseph Merrick Jones Hall, New Orleans, Louisiana 70118 , USA

RICHARD WALL, ESRC Cambridge Group for the History of Population and Social Structure, 27 Trumpington Street, Cambridge CB2 IQA, UK

L. R. POOS, Department of History, Catholic University of America, Washington DC 20064, USA

\section{BOOK REVIEW EDITOR}

Books for review should be sent to J. Boulton, Department of History, University of Newcastle upon Tyne, Newcastle upon Tyne NEI 7RU, UK

\section{EDITORIAL BOARD}

\section{R. AGO, University of Rome \\ C. BROOKS, University of Durham \\ v. BURTON, University of Illinois at Champaign}

A. FAUve, Ecole des Hautes Etudes, Paris

D. KERTZER, Brown University

K. INWOOD, University of Guelph
W. NELSON, New York University
E. OCHIAI, International Research Centre for Japanese Studies, Kyoto
D. SIDDLE, University of Liverpool
R. SMITH, University of Cambridge
P. THANE, University of Sussex
S. WATKINS, University of Pennsylvania

This journal aims to define a field of historical sociology concerned with long-term continuities and discontinuities in the structure of past societies. Emphasis will be upon studies whose agenda or methodology combines elements from traditional fields such as history, sociology, law, demography, economics or anthropology, or ranges freely between them. There will be a strong commitment to comparative studies over a broad range of cultures and time spans.

\section{SUBSCRIPTIONS}

Continuity and Change (ISSN 0268-4160) is published in volumes of three parts. The subscription price which includes postage (excluding VAT) of volume 11, 1996, is $£ 63$ (US \$99) for institutions; $£ 35$ (US \$53) for individuals ordering direct from the Press and certifying that the journal is for their personal use. Single parts cost $£ 21$ (US \$34) plus postage. US dollar prices apply to the USA, Canada and Mexico. EU subscribers (outside the UK) who are not registered for VAT should add VAT at their country's rate. VAT registered subscribers should provide their VAT registration number. Orders, which must be accompanied by payment, may be sent to a bookseller, subscription agent or direct to the publishers: Cambridge University Press, The Edinburgh Building, Shaftesbury Road, Cambridge CB2 2RU, UK. Orders from the USA, Canada and Mexico should be sent to Cambridge University Press, Journals Department, 40 West 20th Street, New York, NY 10011-4211, USA. Copies of the journal for subscribers in the USA, Canada and Mexico are sent by air to New York to arrive with minimum delay. Japanese prices for institutions (including ASP delivery) are available from Kinokuniya Company Ltd, P.O. Box 55, Chitose, Tokyo 156, Japan.

Information on Continuity and Change and all other Cambridge journals is available on http://www.cup.cam.ac.uk/ and in North America on http://www.cup.org/. 